\title{
PENGARUH TERAPI MADU TERHADAP PENURUNAN FREKUENSI BUANG AIR BESAR PADA ANAK USIA 0-2 TAHUN YANG MENGALAMI DIARE DI RUMAH SAKIT UMUM DAERAH DELI SERDANG LUBUK PAKAM TAHUN 2020
}

\author{
Juni Mariati Simarmata ${ }^{1 *}$, Pitriani $^{1}$, Dwi Astuti ${ }^{1}$, Syatriawati Suhaimi ${ }^{1}$, Beti \\ Susanti Tarigan' ${ }^{1}$, Samuel Ginting ${ }^{1}$, Rosita Ginting ${ }^{1}$, Wilda Wahyuni Siregar ${ }^{2}$ \\ ${ }^{1}$ Program Studi Keperawatan, Institut Kesehatan Medistra Lubuk Pakam \\ ${ }^{2}$ Program Studi Sarjana Kebidanan, Institut Kesehatan Medistra Lubuk Pakam \\ Jln. Sudirman No.38 Lubuk Pakam, Kabupaten Deli Serdang, \\ Sumatera Utara - Indonesia \\ *email korespondensi author:: juni_mariati31@yahoo.com
}

DOI $10.35451 /$ jpk.v1i1.755

\begin{abstract}
Abstrak
Diare merupakan suatu penyakit yang ditandai dengan perubahan bentuk dan konsistensi tinja yang lembek sampai mencair dan bertambahnya BAB yang lebih dari biasanya, yaitu 3 kali atau lebih dalam sehari yang mungkin dapat disertai muntah atau tinja yang berdarah. Penyakit diare masih merupakan masalah global dengan derajat kesakitan dan kematian yang tinggi di berbagai negara terutama di negara berkembang dan sebagai salah satu penyebab utama tingginya angka kesakitan dan kematian anak di dunia. Dari studi laboratorium dan uji klinis, madu murni memiliki aktivitas bakterisidal yang dapat melawan beberapa organisme entropathogenic, termasuk diantaranya spesies dari Salmonella, Shigella, dan E.Coli.Tujuan peneliti ini adalah untuk mengetahui pengaruh terapi madu terhadap penurunan BAB pada anak usia 0-2 tahun yang mengalami diare. Penelitian ini dilakukan dengan desain penelitian experiment semu melalui rancangan time series design. Sampel dalam penelitian ini menggunakan tehnik purvosive sampling dengan jumlah 10 orang sebagai responden data yang diperoleh menggunakan lembar observasi dan diuji dengan uji $t$ (paired sample $t$-test) dan bantuan komputer. Dari hasil penelitian yang dilakukan pada 10 orang responden didapat hasil $p<a(0,005<0,05)$ yang menjelaskan ada pengaruh terapi madu terhadap penurunan BAB pada anak usia 0-2 tahun yang mengalami diare di RSUD Lubuk Pakam. Dengan demikian Ho ditolak dan Ha diterima.
\end{abstract}

Kata kunci: Madu, Diare, Balita dan Anak

\begin{abstract}
Diarrhea is a disease characterized by changes in the shape and consistency of stools were soft until melted and increased frequency of bowel movements than usual, which is 3 times or more a day which may be accompanied by vomiting or bloody stools. Diarrheal disease is still a global problem with the degree of morbidity and mortality
\end{abstract}


are high in many countries, especially in developing countries and as one of the major causes of morbidity and mortality of children in the world. From laboratory studies and clinical trials, pure honey has bactericidal activity against several organisms that can entropathogenic, including species of Salmonella, Shigella, and E. coli. The goal of this research was to determine the effect of honey therapy to decrease the frequency of bowel movements in children aged $0-2$ years who had diarrhea in district general hospitals deli serdang Lubuk pakam 2020. This research was conducted by quasi experimental research design through the design time series design, The sample in this study using the technique of sampling purvosive the number of 10 people as respondent data obtained using observation sheets and tested by t-test (paired sample $t$-test) and computer assistance. From the results of research conducted on 10 respondents obtained results $p<a(0.005<0.05)$, which describes the influence of honey therapy to decrease the frequency of bowel movements in children aged 0-2 years who had diarrhea in hospital. Thus Ho is rejected and Ha accepted.

Keywords: Honey, Diarrhea, toddler and child.

\section{Pendahuluan}

Defekasi adalah luaran dari tubuh manusia yang bisa mengalami proses infeksi daalam pelepasan kotoran, peningkatan proses defekasi lebih dari yang diharapkan, yaitu setidaknya 3 kali sehari yang mungkin disertai tanda dan gejala lain yang dapat dinyatakan sebagai masalahnya (Simatupang, 2016).

Diare masih menjadi masalah global dengan morbiditas dan mortalitas yang tinggi yang tinggi di berbagai negara, terutama di negara berkembang dan sebagai salah satu penyebab utama tingginya angka kesakitan dan kematian pada anak di dunia. Umumnya, Diperkirakan lebih dari 10 juta anak berusia kurang dari 5 tahun meninggal setiap tahun Setiap tahun, sekitar 20\% meninggal karena infeksi diare. Meskipun kematian akibat diare dapat dikurangi dengan program rehidrasi/terapi cairan tetapi tingkat nyeri masih tinggi. Saat ini jumlah korban tewas adalah disebabkan oleh diare adalah 3,8 per 1000 per tahun, rata-rata kejadian keseluruhan pada anak di bawah 5 tahun adalah 3,2 episode anak per tahun (Soegianto, 2017).

Besarnya masalah tersebut dapat dilihat dari tingginya angka kesakitan dan kematian akibat diare. Organisasi Kesehatan Dunia (WHO) memperkirakan bahwa 4 miliar kasus terjadi di dunia dan 2,2 juta di antaranya meninggal, dan beberapa di antaranya adalah anak-anak di bawah usia 5 tahun. Meskipun diare membunuh sekitar 4 juta orang/tahun di negara berkembang, ternyata Diare masih menjadi masalah utama di negara maju. Di Amerika, setiap anak mengalami 7-15 episode diare dengan usia rata-rata 5 tahun.

Di negara berkembang, rata-rata setiap anak di bawah usia 5 tahun mengalami episode diare 3 sampai 4 kali per tahun (WHO, 2016). Berdasarkan profil data kesehatan Indonesia pada tahun 2019, setiap tahunnya diperkirakan 2,5 miliar kasus diare pada anak balita, dan hampir tidak ada yang berubah dalam dua dekade terakhir. Diare pada balita lebih dari setengahnya terjadi di Afrika dan Asia Selatan, dapat mengakibatkan kematian atau keadaan serius lainnya. Insiden 
Received: 17 June 2021 :: Accepted: 25 June 2021 ::Published: 30 June 2021

diare bervariasi menurut musim dan umur. Anak-anak adalah kelompok usia rentan terhadap diare, kejadian diare tertinggi pada kelompok anak di bawah usia dua tahun tahun, dan menurun dengan bertambahnya usia. Menurut data Riset Kesehatan Berdasarkan Survei Kesehatan Dasar (Riskesdas) tahun 2014, penyakit diare menempati posisi teratas (nomor satu).

terbanyak) sebagai penyebab kematian bayi (29 hari-11 bulan) dan balita (usia 12-59 bulan). Sementara itu, sebagai penyebab kematian paling umum kedua dalam kelompok bayi dan balita adalah pneumonia (Rikerdas, 2014)

Berdasarkan studi pendahuluan, yang dilakukan peneliti dirumah sakit RSUD Deli Serdang Lubuk Pakam. Peneliti menemukan peningkatan pada pasien yang mengalami kematian pada diare. Dimana pada januari sampai desember 2020 tercatat sekitar 96 pasien yang mengalami diare, dan yang meninggal dunia sebanyak 38 orang, pada bulan januari sampai maret 2020 jumlah kematian juga meningkat pada pasien yang mengalami diare dimana tercatat 110 orang. Dengan jumlah kematian sebanyak 53 orang, dan pada januari sampai maret 2020 jumlah akibat diare semangkin meningkat dengan jumlah pasien sebanyak 120 orang, dan yang meninggal sebanyak 67 orang (RSUD Deli Serdang).

Sejak waktu yang sangat lama madu sudah terkenal ampuh. Madu itu digunakan dalam pengawetan mayat di di papirus sekitar tahun 19000-1250 sebelum masehi. Orang-orang di berbagai belahan dunia sudah mengakui madu sebagai jenis konsumsi bernilai tinggi. Pengetahuan tentang mikroflora saluran cerna dan interaksinya berdampak pada upaya pengembangan dari strategi pemberian diet yang bertujuan untuk meningkatkan mikrobiologi normal dalam saluran cerna maupun pemberian diet yang memilikin aktivitas bacterial. Dari studi laboratorium beberapa organisme seperti entropathogenic dilakukan pengujian melalui uji (Cholid, 2017).

Uji klinis dari pengobatan dengan madu pada anak-anak yang menderita gastroenteritis telah diteliti, para peneliti mendapatkan dengan mengganti glukosa dan elektolit standart seperti yang direkomendasikan WHO/UNICEF, menjadi larutan yang mengandung elektrolit dengan komposisi $48 \mathrm{mmol} / \mathrm{l}$ ion sodium, 28 $\mathrm{mmol} / \mathrm{l}$ ion potassium, $76 \mathrm{mmol} / \mathrm{l}$ ion chloride ditambah madu $50 \mathrm{ml} / \mathrm{l}$, ratarata waktu pemulihan pada manusia (usia 8 hari-11 tahun) berkembang secara signifikan. Tingginya kandungan fruktosa dan glukosa dari madu diperkirakan dapat berguna untuk membantu penyerapan sodium dan air di dalam usus.

Bahan-bahan mineral dengan presentase $18,0 \%$. Meskipun jumlah presentasenya kecil, namun ia memiliki peran penting. Karena madu bisa menjadi makanan yang memiliki kemampuan basa untuk menghancurkan asam. Hal ini juga sangat penting dalam proses menyembuhkan penyakit yang menyerang organ pencernaan yang disebabkan oleh sebab adanya kelebihan asam dan peradangan Kandungan madu merupakan bahan pemanis buatan yang paling baik buat anak-anak. Karena disamping rasa manis yang dimilikinya, madu juga mengandung sejumlah kecil protein, mineral, dan madu juga dapat mensterilkan dan melembutkan usus pencernaan.

\section{Metode}

Desain penelitian quasi experiment (experiment semu) dengan model rancangan time series design. Yaitu sebelum dilaksanakannya perlakuan 
maka dilakukan observasi pada sampel (Notoadmodjo, 2018).

Pemilihan penderita diare yang menjadi sampel penelitian. Selanjutnya, dilakukan pengukuran frekuensi $B A B$ (observasi pre-test). Setelah itu diberikan tindakan terapi madu yang kemudian akan diukur kembali (observasi). Populasi adalah adalah area generalisasi yang terdiri dari: Objek/mata pelajaran yang memiliki hal dalam menarik kesimpulan penelitian (Notoadmodjo, 2017).

Pada penelitian ini adalah seluruh pasien yang mengalami diare di Rumah Sakit Umum Deli Serdang Lubuk Pakam periode pada bulan Januari- Maret 2020 pasien diare usia balita sebanyak 120 orang. Yang diteliti atau bagian dari jumlah karakteristik dimiliki oleh penduduk dijadikan sebagai sampel. Sampel dalam penelitian adalah pasien diare di Rumah Sakit Umum Daerah Deli Serdang Lubuk Pakam yaitu sebanyak 10 orang.

Pada penelitian ini tehnik sampel yang digunakan adalah nonprobability sampling dengan purposive sampling yaitu: Tehnik penentuan sampel berdasarkan pertimbangan tertentu untuk membatasi karakteristik dari sampel.

\section{Hasil Dan Pembahasan}

a. Karakteristik Responden Meliputi Jenis Kelamin dan Usia

Tabel 1. Distribusi Frekuensi

Karakteristik Responden Meliputi Jenis Kelamin dan Usia

\begin{tabular}{|c|c|c|c|c|}
\hline $\begin{array}{l}N \\
0\end{array}$ & $\begin{array}{l}\text { Karakteristi } \\
\text { k } \\
\text { Responden }\end{array}$ & & $(\mathrm{N})$ & $\%$ \\
\hline \multirow[t]{3}{*}{1} & Jenis & Laki-laki & 7 & 70,0 \\
\hline & Kelamin & $\begin{array}{l}\text { Peremp } \\
\text { uan }\end{array}$ & 3 & 30,0 \\
\hline & & Jumlah & 10 & 100 \\
\hline \multirow[t]{2}{*}{2} & Usia & $<=8$ & 2 & 20,0 \\
\hline & & bulan & 5 & 50,0 \\
\hline
\end{tabular}

\begin{tabular}{ccc}
\hline & $9-163 \quad 30,0$ \\
& bulan \\
& $>=17$ \\
& bulan \\
\hline & Jumlah 10 \\
\hline Dari tabel tersebut, bahwa usia
\end{tabular}
responden mayoritas berjenis kelamin laki-laki yaitu sebanyak 7 orang $(70,0 \%)$ dan berjenis kelamin perempuan sebanyak 3 orang $(30,0 \%)$. Responden yang berusia $<=8$ bulan yaitu sebanyak 2 orang $(20,0 \%), 9-16$ bulan sebanyak 5 orang $(50,0 \%),>=17$ bulan sebanyak 3 orang (30,0\%).

b. Penurunan BAB pada anak sebelum dilakukankan terapi madu

Dari tabel dibawah dapat dilihat bahwa dengan menggunakan lembar observasi sebelum dilakukan terapi madu, terdapat mayoritas 5 responden (50\%) dengan BAB $6 \mathrm{x} /$ hari, 1 responden $(10 \%)$ dengan $B A B 3 \times /$ hari, 3 responden (30\%) dengan $B A B 5$ $\mathrm{x} /$ hari, dan 1 responden (10\%) dengan BAB7 $x /$ hari. Penurunan BAB pada anak sebelum dilakukankan terapi madu mempunyai pengaruh ketika sesudah peberian madu pada usia anak tersebut.

Tabel 2. Distribusi Frekuensi penurunan BAB pada anak sebelum dilakukankan terapi mad

\begin{tabular}{lcccc}
\hline $\begin{array}{l}\text { sebe } \\
\text { lum } \\
\begin{array}{l}\text { (x/h } \\
\text { ari })\end{array}\end{array}$ & Fre & $\%$ & Valid & \\
\hline & 1 & 1 & 10.0 & 10.0 \\
& 3 & 0 & 30.0 & 40.0 \\
3 & 5 & 3 & 50.0 & 90.0 \\
5 & 1 & 0 & 10.0 & 100.0 \\
6 & & 5 & & \\
7 & & 0 & & \\
& & 1 & & \\
& & 0 & & \\
\hline Ju & 1 & 1 & 100.0 & \\
mla & 0 & 0 & & \\
h & & 0 & & \\
\hline
\end{tabular}


c. penurunan frekuensi $B A B$ sesudah dilakukan terapi madu

Tabel 3. Distribusi Frekuensi penurunan pada anak sesudah dilakukankan terapi madu

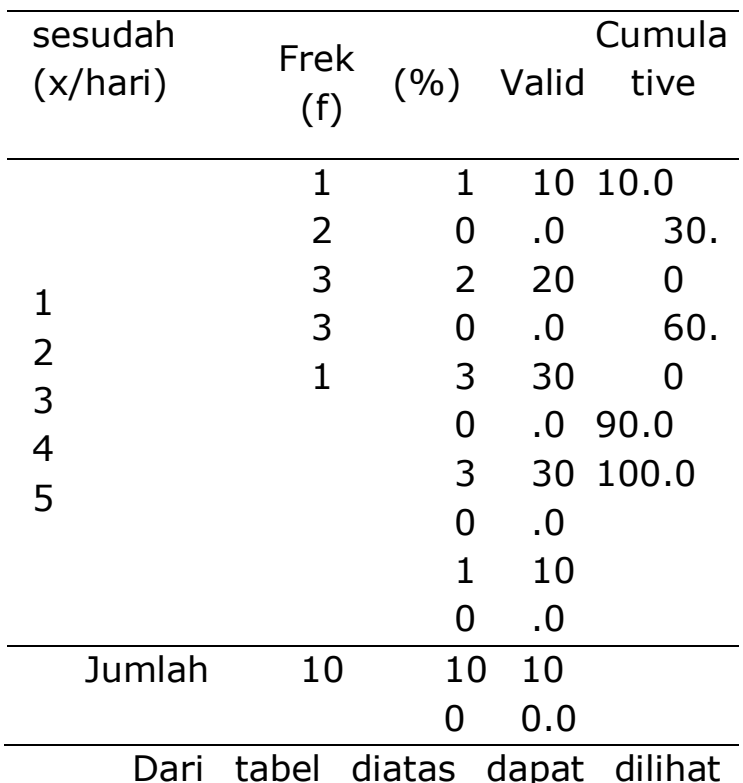

bahwa mayoritas responden mengalami penurunan $B A B$ sebanyak 3 responden (30\%) dengan $B A B 3 \mathrm{x} /$ hari, 3 responden (30\%) dengan $B A B 4 \mathrm{x} /$ hari, 1 responden (10\%) dengan $B A B 1$ $x /$ hari, 2 responden $(20 \%)$ dengan $B A B$ $4 \mathrm{x} /$ hari, dan 1 responden (10\%) dengan BAB $5 \times$ /hari.

\section{Kesimpulan}

Menurut hasil pengabdian dan pembahasan tersebut diatas bahwa dapat disimpulkan bahwa pengaruh terapi madu terhadap penurunan $B A B$ pada anak di RSUD Lubuk Pakam:

a. BAB sebelum diberikan terapi madu terdapat mayoritas 5 responden (50\%) dengan BAB $6 \mathrm{x} /$ hari, 1 responden $(10 \%)$ dengan $B A B 3$ $\mathrm{x} /$ hari, 3 responden $(30 \%)$ dengan BAB5 $x /$ hari, dan 1 responden $(10 \%)$ dengan $B A B 7 \times /$ hari.

b. BAB sesudah diberikan terapi madu menunjukkan bahwa, mayoritas responden mengalami penurunan BABsebanyak 3 responden (30\%) dengan $B A B 3 x /$ hari, 3 responden (30\%) dengan $B A B \quad 4$ x/hari, 1 responden $(10 \%)$ dengan $B A B 1$ $\mathrm{x} /$ hari, 2 responden (20\%) dengan $\mathrm{BAB} 4 \mathrm{x} /$ hari, dan 1 responden (10\%) dengan $B A B 5 \times$ /hari.

c. Ada pengaruh terapi madu terhadap penurunan BAB pada anak. Berdasarkan hasil uji statistik; $\mathrm{p} \leq$ dari 0,05 yaitu $p=0,001$.

\section{Ucapan Terima Kasih}

a. Kepada Direktur RSUD Deli Serdang Terimakasih karena atas izin beliau pengmas ini dapat berjalan dengan baik

b. Kepada pimpinan Inkes Medistra L.Pakam

Terimakasih karena membantu pendanaan dalam melaksanakan proses pengabdian masyarakat.

\section{Daftar Pustaka}

Abdullah, Muhammad. (2017). Rahasia Sehat Bersama Madu Lebah.Penerbit: Insan Kamil, Solo. Ahmad.2011. Manfaat Madu Bagi Kita. Diunduh pada tanggal 01 April 2020

dari:http://manfaatmadu.com.

Arikunto,SuharsimiProfDr.2018.Pr osedur Penelitian Suatu Pendekatan Praktik.Edisi Ke 6.Penerbit: PT Rineka Cipta, Jakarta.

F.P,Anandita.2012.Mengenal Bahaya Penyakit Diare.Edisi pertama.Penerbit: Yudhistira, Bogor.

Ginting,Josia.2019.Tatalaksana Penderita Diare. Dari : http://depkes.go.id/diarepdf

Muhammad, S.B. Abdul.2018.Ketika Rasulullah Tidak Perrnah Sakit.Cetakan Pertama.Penerbit: Tinta Medina, Solo.

Notoadmojo,Soekidjo.2019.Metodologi Penelitian Kesehatan. 
Penerbit: PT.Rineka Cipta, Jakarta.

Nurlaelah, Alliyah.2016.100\%Insya Allah Sembuh.Penerbit:Lukita, Yogyakarta.

Nursalam, 2019. Konsep dan Penerapan Metodologi Penelitian Ilmu Keperawatan. Selemba Medika, Jakarta

Rizema, Sitiatava Putra.2020.Asuhan Neonatus Bayi dan Balita untuk Keperawatan dan Kebidanan.Edisi pertama.Penerbit: D-MEDIKA, Jogjakarta.

Sa'id. Ahmad Prof Dr.2019.Terapi Madu.Penerbit: Pustaka Iiman, Depok.

Sastroasmoro,sudigdo.Prof.Dr.2018.Das ar-dasar Metodologi Penelitian Klinis. Penerbit: Sagung Seto, Jakarta.

Soegianto.2017. Masalah Dalam Penatalaksanaan Diare Akut pada Orang Dewasa. Diunduh pada tanggal 25 Maret 2020 dari:http://masalahdiare.com.

Soewondo,ES.2012. Penatalaksanaan diare akut akibat infeksi. Diunduh pada tanggal 28 Maret 2018 dari: http://depkes.go.id/penatalaksan aandiarepdf.

Sugiyono, Prof Dr.2019.Metodologi Penelitian Administrasi.Cetakan Ke 14.Penerbit: Alfabeta, Bandung.

Zein,Umar.2012.Pedoman Pemberantasan Penyakit Diare. Diunduh pada tanggal 02 April 2020 dari : http://depkes.go.id/penyakitdiare -pdf. 